\title{
Marble Waste Valorization through Alkali Activation
}

\author{
Konstantinos Komnitsas ${ }^{1, *(\mathbb{D})}$, Athanasia Soultana ${ }^{1}$ and Georgios Bartzas ${ }^{2}$ (D) \\ 1 School of Mineral Resources Engineering, Technical University of Crete, 73100 Chania, Greece; \\ asoultana@isc.tuc.gr \\ 2 School of Mining and Metallurgical Engineering, National Technical University of Athens, \\ 15780 Zografos, Greece; gbartzas@metal.ntua.gr \\ * Correspondence: komni@mred.tuc.gr; Tel.: +30-28210-37686
}

\section{check for}

updates

Citation: Komnitsas, K.; Soultana, A.; Bartzas, G. Marble Waste Valorization through Alkali Activation. Minerals 2021, 11, 46. https://doi.org/ $10.3390 / \min 11010046$

Received: 5 November 2020 Accepted: 29 December 2020 Published: 2 January 2021

Publisher's Note: MDPI stays neutral with regard to jurisdictional clai$\mathrm{ms}$ in published maps and institutional affiliations.

Copyright: $\odot 2021$ by the authors. Licensee MDPI, Basel, Switzerland. This article is an open access article distributed under the terms and conditions of the Creative Commons Attribution (CC BY) license (https:// creativecommons.org/licenses/by/ $4.0 /)$.

\begin{abstract}
In the present study, the valorization potential of marble waste in the presence of metakaolin via alkali activation was explored. The activating solution used consisted of $\mathrm{NaOH}$ and sodium silicate solutions. The effects of marble waste to metakaolin ratio, particle size of raw materials, curing temperature, and $\mathrm{Na}_{2} \mathrm{O} / \mathrm{SiO}_{2}$ and $\mathrm{H}_{2} \mathrm{O} / \mathrm{Na}_{2} \mathrm{O}$ molar ratios present in the activating solution on the main properties and the morphology of the produced alkali-activated materials (AAMs) was evaluated. The durability and structural integrity of the AAMs after firing at temperatures between 200 and $600{ }^{\circ} \mathrm{C}$, immersion in deionized water and $1 \mathrm{~mol} / \mathrm{L} \mathrm{NaCl}$ solution for different time periods and subjection to freeze-thaw cycles were also investigated. Characterization techniques including Fourier transform infrared spectroscopy, X-ray diffraction, mercury intrusion porosimetry and scanning electron microscopy were used in order to study the structure of the produced AAMs. The highest compressive strength $(\sim 36 \mathrm{MPa})$ was achieved by the AAMs prepared with marble waste to metakaolin mass ratio of 0.3 after curing at $40^{\circ} \mathrm{C}$. The results indicated that the utilization of marble waste in the presence of metakaolin enables the production of AAMs with good physical (porosity, density and water absorption) and mechanical properties, thus contributing to the valorization of this waste type and the reduction of the environmental footprint of the marble industry.
\end{abstract}

Keywords: marble waste; metakaolin; alkali activation

\section{Introduction}

Marbles are natural stones which are formed as a result of recrystallization of limestone and dolomite under high temperature and pressure [1]. They are used since ancient times for the construction of cultural heritage monuments, historical buildings and numerous other applications. Their economic value depends both on their morphological and structural characteristics. Worldwide, there exist various types and significant reserves of marbles which they account for about $50 \%$ of the total natural stones production $[2,3]$. Due to the processing requirements and environmental limitations, only $10 \%$ of the quarrying material is used in the market [4]. Cutting and polishing processes in marble plants result in the production of two types of waste, namely marble waste slurry and marble waste powder. Thus far, the ornamental stone industry has not developed an efficient valorization process for these waste types, therefore they are either stored in warehouses for future use in other applications, or disposed of in landfills, causing environmental problems [5,6].

Marble waste can be used as replacement of aggregates or additive in concrete production [7], as well as raw material for up to $30 \mathrm{wt}$. \% substitution of red clay during the production of bricks for the improvement of their properties [8,9]. Thus, the higher use of marble waste in construction applications, via a technically and economically feasible technology, can result in significant economic and environmental benefits for the quarrying industry [10].

Alkali activation is a promising technology for the valorization of various waste types and the production of secondary materials, termed alkali-activated materials (AAMs), 
inorganic polymers or geopolymers. AAMs have amorphous/semi-crystalline structure and their production is based on the dissolution of silicon and aluminum from raw materials with the use of $\mathrm{NaOH}$ or $\mathrm{KOH}$ and silicate solutions, followed by the formation of a reactive paste, which hardens after mild temperature curing. The factors that affect the properties of the produced AAMs are the content of the aluminosilicates, the particle size of the precursors and the synthesis conditions. Over the last 20 years, AAMs with excellent physical, chemical and thermal properties have been produced [11-17].

The valorization of the wastes produced by the marble and the entire dimensionstone industry via alkali activation has attracted so far limited interest by the industry and the research community. Wang et al. [18] investigated the potential of the addition of marble and granite waste as aggregate, for the production of blast furnace slag-based inorganic polymers. Based on their results, marble addition enhanced the bonding strength of the produced inorganic polymers compared to granite-based ones because of its higher dissolution obtained in the polymeric matric. The use of marble waste was also investigated along with other materials such as travertine and volcanic tuff for the production of AAMs under dry and wet curing conditions [5]. In this study, the produced AAMs acquired similar compressive strength under both conditions for all the starting mixtures tested; however, the highest compressive strength $(46 \mathrm{MPa})$ was obtained under dry curing at $20{ }^{\circ} \mathrm{C}$. Colangelo et al. [19] investigated the addition of marble waste as filler in a binder mixture consisting of metakaolin-based inorganic polymer, epoxy resin and expanded polystyrene, for the production of thermal insulating materials. The results showed that milled marble waste, with size smaller than $300 \mu \mathrm{m}$, resulted in the production of AAMs with improved mechanical properties and reduced drying shrinkage. Coppola et al. [20] developed AAMs using as raw materials marble sludge and waste glass powder and investigated the effect of different curing conditions, using dry and humid environment, on their morphology and properties. The results showed that the dissolution of calcium ions from marble waste promoted the formation of (N)-C-S-H gel and thus the air-cured AAMs acquired high compressive strength, almost $45 \mathrm{MPa}$. Finally, Simão et al. [21] used calciterich stone cutting waste, namely from marble and volcanic stone, for the production of metakaolin-based inorganic polymers with beneficial mechanical properties. In this study, the calcite-rich waste was used as an effective replacement of metakaolin, and resulted in the production of specimens which acquired compressive strength of $29 \mathrm{MPa}$, mainly due to the lower water requirements of the starting alkaline mixture.

The present study investigates the valorization potential of marble wastes, mixed with metakaolin, via alkali activation. The addition of metakaolin, due to its high $\mathrm{Al}$ and Si content, aims to substantially improve the poor inherent alkali activation potential of marble waste and enable the production of AAMs with beneficial properties.

\section{Materials and Methods}

Marble waste with an initial size of $<32 \mathrm{~mm}$ was obtained from a marble processing plant located in the island of Crete (Greece), while metakaolin was produced by calcination of commercial kaolin (Fluka, Switzerland) at $750{ }^{\circ} \mathrm{C}$ for $2 \mathrm{~h}$. Metakaolin was used in this study for the regulation of the ratio of $\mathrm{SiO}_{2} / \mathrm{Al}_{2} \mathrm{O}_{3}$ in the starting mixture of the raw materials in order to facilitate the formation of aluminosilicate phases during alkali activation [15]. Marble waste was first crushed in a Fritsch-type jaw crusher (Fritsch, Germany) to a particle size $<8 \mathrm{~mm}$ and then pulverized using a Sepor-type rod mill (Sepor, Los Angeles, CA, USA) and a Bico-type pulverizer (Fritsch, Dresden, Germany) to obtain a fine-grained material. Three different particle size fractions were obtained, after 60 and $90 \mathrm{~min}$ of grinding in the rod mill and after $2 \mathrm{~min}$ of grinding in the pulverizer [22], in order to evaluate the effect of the particle size on the compressive strength of the produced AAMs. The particle size analysis of marble waste and metakaolin was determined with the use of a laser particle size analyzer Mastersizer-S (Malvern Instruments, Malvern, UK) and is given in Table 1. It is seen from these data that both materials were pulverized to a very 
fine size. For example, the $d_{50}(50 \%$ passing) of marble waste was $<18 \mu \mathrm{m}$ for all the three sample fractions obtained, while that of metakaolin was $<9 \mu \mathrm{m}$.

Table 1. Particle size $(\mu \mathrm{m})$ of raw materials.

\begin{tabular}{ccccc}
\hline \multirow{2}{*}{ Particle Size } & \multicolumn{3}{c}{ Marble Waste } & \multirow{2}{*}{ Metakaolin } \\
\cline { 2 - 4 } & Size $\mathbf{1}$ & Size 2 & Size 3 & \\
\hline $\mathrm{d}_{90}$ & 100.9 & 86.8 & 48.9 & 25.5 \\
$\mathrm{~d}_{50}$ & 17.9 & 14.5 & 8.1 & 8.8 \\
$\mathrm{~d}_{10}$ & 1.1 & 1.0 & 0.6 & 2.1 \\
\hline
\end{tabular}

The chemical composition of the raw materials was determined with the use of an X-ray fluorescence energy dispersive spectrometer (XRF-EDS) S2 Range type (Bruker, Karlsruhe, Germany) and is shown in Table 2. As seen from these data, metakaolin may act as source of silicon and aluminum (55.9 wt. \% $\mathrm{SiO}_{2}$ and $38.5 \mathrm{wt}$. \% $\mathrm{Al}_{2} \mathrm{O}_{3}$ ), elements which are required for alkali activation, whereas marble waste has, as anticipated, high content of $\mathrm{CaO}$ (53.1 wt. \%).

Table 2. Chemical composition (wt. \%) of raw materials.

\begin{tabular}{ccc}
\hline Oxides & Marble Waste & Metakaolin \\
\hline $\mathrm{SiO}_{2}$ & 0.9 & 55.9 \\
$\mathrm{Al}_{2} \mathrm{O}_{3}$ & 0.1 & 38.5 \\
$\mathrm{CaO}$ & 53.1 & 0.0 \\
$\mathrm{Na}_{2} \mathrm{O}$ & 0.7 & 0.6 \\
$\mathrm{Fe}_{2} \mathrm{O}_{3}$ & 0.5 & 0.5 \\
$\mathrm{MgO}$ & 1.5 & 0.0 \\
$\mathrm{~K}_{2} \mathrm{O}$ & 0.0 & 2.1 \\
$\mathrm{LOI}$ & 41.8 & 1.6 \\
Total & 98.6 & 99.2 \\
\hline
\end{tabular}

${ }^{*}$ Loss on ignition determined after heating of the materials at $1050^{\circ} \mathrm{C}$ for $4 \mathrm{~h}$.

The activating solution consisted of sodium silicate solution $\left(\mathrm{Na}_{2} \mathrm{O}=7.5-8.5 \mathrm{wt}\right.$. \%, $\mathrm{SiO}_{2}=25.5-28.5$ wt. \%, Merck, Germany) and $\mathrm{NaOH}$ solution (6-10 mol/L). The NaOH solution was produced by dissolving anhydrous pellets of $\mathrm{NaOH}$ in distilled water so that the desired molarity was obtained. Table 3 shows the mixing proportions of the raw materials and reagents used as well as the $\mathrm{SiO}_{2} / \mathrm{Al}_{2} \mathrm{O}_{3}$ molar ratio in the starting mixture, the $\mathrm{Na}_{2} \mathrm{O} / \mathrm{SiO}_{2}$ and $\mathrm{H}_{2} \mathrm{O} / \mathrm{Na}_{2} \mathrm{O}$ molar ratios in the activating solution and the overall liquid/solid (L/S) ratio. Specific proportions of marble waste and metakaolin were used in order to obtain suitable $\mathrm{SiO}_{2} / \mathrm{Al}_{2} \mathrm{O}_{3}$ ratios in the precursors, based on the results of earlier studies carried out in our lab as well as by using literature data. [11,23]. The resulting paste was obtained after mechanical mixing of the raw materials with the activating solution for $10 \mathrm{~min}$. The activating solution was prepared by mixing the solutions used and was left overnight prior to use. As seen in Table 3, three different $\mathrm{H}_{2} \mathrm{O} / \mathrm{Na}_{2} \mathrm{O}$ molar ratios were used in the experimental series in order to obtain a slurry with suitable fluidity and workability, while at the same time maintaining in all cases the lowest possible L/S ratio, which in our case varies slightly between 0.49 and 0.54 [24]. It is mentioned that in other earlier studies carried out in our labs with the use of other wastes, e.g., slags and construction and demolition wastes, this ratio was much lower, i.e., 0.20-0.30 [12,17]. The produced paste was poured in steel cubic molds $\left(5 \times 5 \times 5 \mathrm{~cm}^{3}\right)$ and remained at room temperature for either $2 \mathrm{~h}$ (metakaolin-based (MK) specimens) or $4 \mathrm{~h}$ (marble wastemetakaolin (MW/MK) specimens) to facilitate sufficient initial setting and hardening. The specimens were then demolded, placed in sealed plastic bags and cured at 40,60 and $90{ }^{\circ} \mathrm{C}$ for $24 \mathrm{~h}$ in a laboratory oven ON-02G (Jeio Tech, Billerica, MA, USA). After curing, the specimens were removed from the oven, aged at room temperature for 7 days and their compressive strength was determined using a Matest compression machine with dual 
range 500/15 kN (Matest, Bergamo, Italy). Measurements were carried out in triplicate and in the paper mean values are given. It is mentioned that deviation of measurements was marginal and did not exceed $\pm 3.5 \%$.

Table 3. Typical mix proportions (wt. \%) of raw materials and reagents. The last four columns show the molar ratios $\mathrm{SiO}_{2} / \mathrm{Al}_{2} \mathrm{O}_{3}$ in the starting mixture as well as the $\mathrm{Na}_{2} \mathrm{O} / \mathrm{SiO}_{2}$ and $\mathrm{H}_{2} \mathrm{O} / \mathrm{Na}_{2} \mathrm{O}$ molar ratios in the activating solution and the overall liquid/solid (L/S) ratio.

\begin{tabular}{ccccccccc}
\hline $\begin{array}{c}\text { Marble } \\
\text { Waste }\end{array}$ & Metakaolin & $\mathbf{N a O H}$ & $\mathbf{H}_{\mathbf{2}} \mathbf{O}$ & $\mathbf{N a}_{\mathbf{2}} \mathbf{S i O}_{\mathbf{3}}$ & $\mathbf{S i O}_{\mathbf{2}} / \mathbf{A l}_{\mathbf{2}} \mathbf{O}_{\mathbf{3}}$ & $\mathbf{N a}_{\mathbf{2}} \mathbf{O} / \mathbf{S i O}_{\mathbf{2}}$ & $\mathbf{H}_{\mathbf{2}} \mathbf{O} / \mathbf{N a}_{\mathbf{2}} \mathbf{O}$ & $\mathbf{L} / \mathbf{S}$ \\
\hline 60 & - & 6 & 15 & 19 & 15.3 & 1.1 & 14.9 & 0.53 \\
- & 54 & 6 & 17 & 23 & 2.4 & 1.0 & 16.0 & 0.66 \\
13 & 49 & 3 & 16 & 19 & 2.9 & 0.8 & 22.0 & 0.54 \\
13 & 49 & 4 & 15 & 19 & 2.9 & 0.9 & 18.5 & 0.51 \\
13 & 49 & 5 & 14 & 19 & 2.9 & 1.0 & 16.0 & 0.49 \\
25 & 37 & 3 & 16 & 19 & 3.0 & 0.8 & 22.0 & 0.54 \\
25 & 37 & 4 & 15 & 19 & 3.0 & 0.9 & 18.5 & 0.51 \\
25 & 37 & 5 & 14 & 19 & 3.0 & 1.0 & 16.0 & 0.49 \\
37 & 25 & 3 & 16 & 19 & 3.2 & 0.8 & 22.0 & 0.54 \\
37 & 25 & 4 & 15 & 19 & 3.2 & 0.9 & 18.5 & 0.51 \\
37 & 25 & 5 & 14 & 19 & 3.2 & 1.0 & 16.0 & 0.49 \\
\hline
\end{tabular}

The mineralogy, structure and morphology of selected AAMs was determined by X-ray diffraction (XRD), Fourier Transform Infrared Spectroscopy (FTIR), Mercury Intrusion Porosimetry (MIP) and Scanning Electron Microscopy (SEM). XRD analysis was performed using an X-ray diffractometer (D8-Advance, Bruker AXS, Bruker, Karlsruhe, Germany) with a $\mathrm{Cu}$ tube, a scanning range from $4^{\circ}$ to $70^{\circ} 2$-theta $(\theta)$ with a step $0.02^{\circ}$ and a measuring time of $0.2 \mathrm{~s} / \mathrm{step}$. Qualitative analysis was carried out using the DiffracPlus Software (Bruker AXS, Bruker, Karlsruhe, Germany) and the PDF database. Fourier Transform Infrared Spectroscopy (FTIR) was performed using $\mathrm{KBr}$ pellets with a PerkinElmer 1000 spectrometer (PerkinElmer, Akron, OH, USA). MIP analysis was performed using a Micromeritics AutoPore 9400 porosimeter (Micromeritics, Atlanta, GA, USA). Scanning Electron Microscopy (SEM) was carried out using a JEOL 6380LV (JEOL, Tokyo, Japan) microscope equipped with an Oxford INCA energy dispersive X-ray spectrometer (EDS) microanalysis system (Oxford Instruments, Abingdon, UK). Prior to SEM analysis, AAM specimens were stored in an anaerobic glove box and then embedded in an epoxy resin (EpoFix, Struers, Ballerup, Denmark). The epoxy-embedded samples were ground and polished using diamond abrasives. The apparent density and the water absorption of selected AAMs were also determined according to BS EN 1936:2006 [25] and BS EN 13755:2008 [26] standards, respectively.

In order to study their structural integrity, selected AAMs were (i) subjected to firing at 200, 400 and $600{ }^{\circ} \mathrm{C}$ for $2 \mathrm{~h}$, in a laboratory furnace N-8L Selecta (JP Selecta, Abrera, Spain), (ii) immersed in deionized water and $1 \mathrm{~mol} / \mathrm{L}(\mathrm{M}) \mathrm{NaCl}$ solution for 7 and 30 days and (iii) subjected to 7 and 15 freeze-thaw cycles, according to ASTM 1262-10 [27]. AAMs were subjected to freezing at minus $17^{\circ} \mathrm{C}$ for $4 \mathrm{~h}$ and thawing at room temperature for $18 \mathrm{~h}$ (one complete cycle). After each test, the weight loss and the compressive strength of the specimens were determined.

\section{Results}

\subsection{Effect of Marble Waste to Metakaolin Ratio}

Figure 1 illustrates the compressive strength of the AAMs produced after curing of the reactive paste at $90^{\circ} \mathrm{C}$ for 7 days, using different marble waste (median particle size $17.9 \mu \mathrm{m}$ ) to metakaolin mass ratios (MW/MK 0.3, 0.7 and 1.5 AAMs) as a function of $\mathrm{H}_{2} \mathrm{O} / \mathrm{Na}_{2} \mathrm{O}$ molar ratio present in the activating solution (16.0, 18.5 and 22.0). The compressive strength of MK and MW reference AAMs is also given for comparison. 


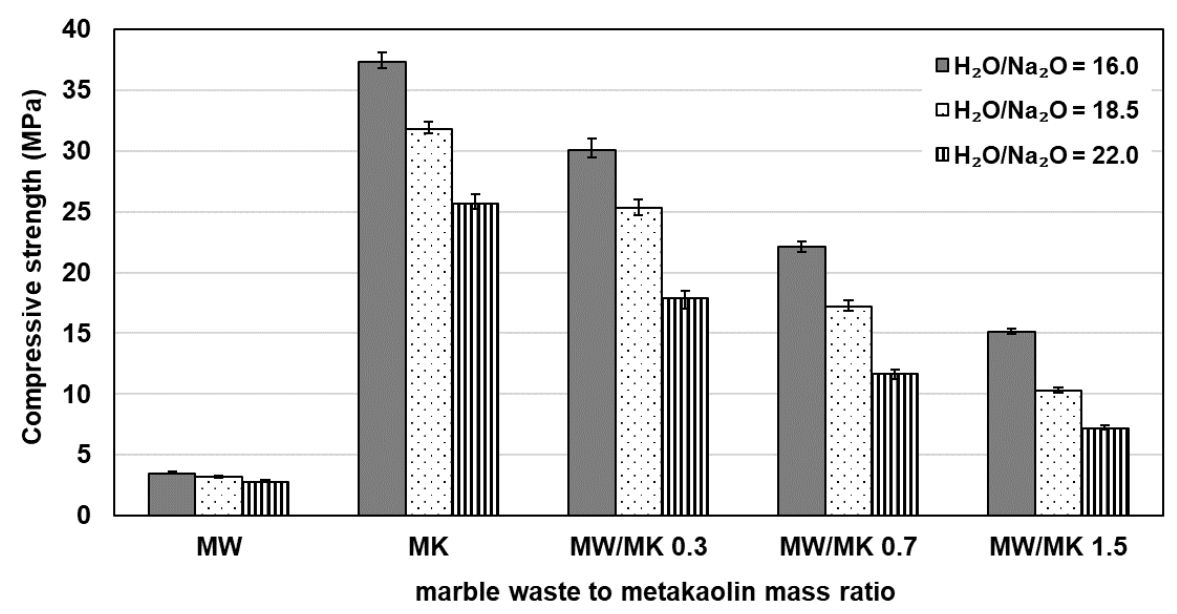

Figure 1. Effect of marble waste to metakaolin mass ratio on the 7-day compressive strength of the produced specimens after curing at $90{ }^{\circ} \mathrm{C}$ for $24 \mathrm{~h}$, as a function of $\mathrm{H}_{2} \mathrm{O} / \mathrm{Na}_{2} \mathrm{O}$ molar ratios in the activating solution. The compressive strength of reference $\mathrm{MW}$ and $\mathrm{MK}$ specimens is also given for comparison.

As seen in Figure 1, the MW reference specimens exhibited very low compressive strength for all the $\mathrm{H}_{2} \mathrm{O} / \mathrm{Na}_{2} \mathrm{O}$ molar ratios used, indicating the poor alkali activation potential of marble waste, due to its extremely low content of silica and alumina, as shown in Table 2. On the other hand, the MK reference specimens exhibited much higher compressive strength, which in all cases exceeded $25 \mathrm{MPa}$ and reached in the optimum synthesis conditions $37.3 \mathrm{MPa}$. This is the reason why marble waste was mixed with metakaolin which due to its high content of silica and alumina possesses a much higher inherent alkali activation potential; the beneficial behavior of metakaolin during alkali activation has been underlined by many researchers who investigated mixtures of metakaolin and various municipal and industrial wastes for the production of AAMs with good mechanical and physico-chemical properties [28-34].

The specimens produced after alkali activation of the mixtures containing marble waste and metakaolin acquired quite high compressive strength. The highest value (30.1 MPa) was acquired by the specimens produced with the use of marble waste to metakaolin ratio 0.3 (MW/MK $0.3 \mathrm{AAM}$ ) and $\mathrm{H}_{2} \mathrm{O} / \mathrm{Na}_{2} \mathrm{O}$ molar ratio 16 . Relatively high compressive strength values, namely 22.3 MPa and $15.2 \mathrm{MPa}$, were also obtained when the same $\mathrm{H}_{2} \mathrm{O} / \mathrm{Na}_{2} \mathrm{O}$ molar was used and the marble waste to metakaolin ratio in the starting mixture increased to 0.7 and 1.5, respectively. The decrease of the compressive strength values when higher marble waste to metakaolin mass ratios were used is due to the inherent poor alkali activation potential of marble waste, as mentioned earlier in this paper.

It is also seen in Figure 1 that the increase of $\mathrm{H}_{2} \mathrm{O} / \mathrm{Na}_{2} \mathrm{O}$ molar ratio from 16 to 22, resulted in a noticeable decrease of the compressive strength for all produced AAMs. Lower $\mathrm{H}_{2} \mathrm{O} / \mathrm{Na}_{2} \mathrm{O}$ ratios denote that stronger activating solution is used which has the ability to provide the required alkalinity in the produced reactive paste that results in sufficient dissolution of $\mathrm{Si}$ and $\mathrm{Al}$ from the precursors and the formation of stronger Si-O-Al bonds $[35,36]$.

\subsection{Effect of Curing Temperature}

The effect of curing temperature $\left(40,60\right.$ and $\left.90^{\circ} \mathrm{C}\right)$ on the compressive strength of the AAMs produced using marble waste (median particle size $17.9 \mu \mathrm{m}$ ) to metakaolin mass ratio 0.3 and $\mathrm{H}_{2} \mathrm{O} / \mathrm{Na}_{2} \mathrm{O}$ molar ratio in the activating solution 16, is illustrated in Figure 2. The compressive strength of MK and MW reference AAMs is given again for comparison. 


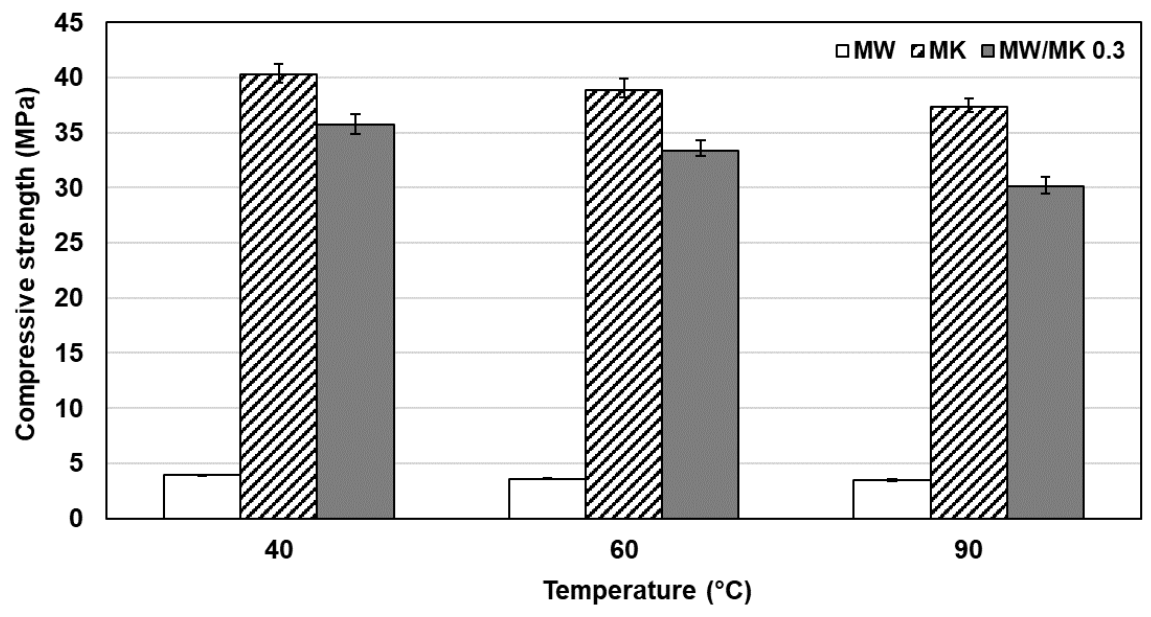

Figure 2. Effect of curing temperature on the 7-day compressive strength of alkali-activated materials (AAMs) produced with the use of marble waste to metakaolin mass ratio 0.3 and $\mathrm{H}_{2} \mathrm{O} / \mathrm{Na}_{2} \mathrm{O}$ molar ratio in the activating solution 16 (median MW particle size $17.9 \mu \mathrm{m}$ ).

As seen from the data, the effect of the curing temperature over the range investigated was marginal and thus its increase from 40 to $90^{\circ} \mathrm{C}$ had only a slightly negative effect on the compressive strength of the produced AAMs. The highest compressive strength (35.7 MPa) was acquired by the AAMs produced after curing at $40^{\circ} \mathrm{C}$. Although in most cases curing at elevated temperatures is known to accelerate the rate of the alkali activation reactions $[15,37]$, in this case the process was carried out effectively even at the low temperature of $40^{\circ} \mathrm{C}$; this was mainly due to the presence of sufficient metakaolin, which has significant alkali activation potential at low temperature, as also indicated in previous studies [38-41]. It is thus underlined that the use of low temperature during curing is beneficial since it results in significant economic and environmental benefits, which are associated with lower energy cost and lower emissions due to reduced energy consumption.

\subsection{Effect of Marble Waste Particle Size on the Compressive Strength}

Figure 3 illustrates the effect of median particle size of marble waste $(8.1,14.5$ or $17.9 \mu \mathrm{m})$ on the compressive strength of AAMs produced using marble waste to metakaolin mass ratio 0.3 (MW/MK $0.3 \mathrm{AAM}$ ), $\mathrm{H}_{2} \mathrm{O} / \mathrm{Na}_{2} \mathrm{O}$ molar ratio 16 , and curing temperature $40{ }^{\circ} \mathrm{C}$.

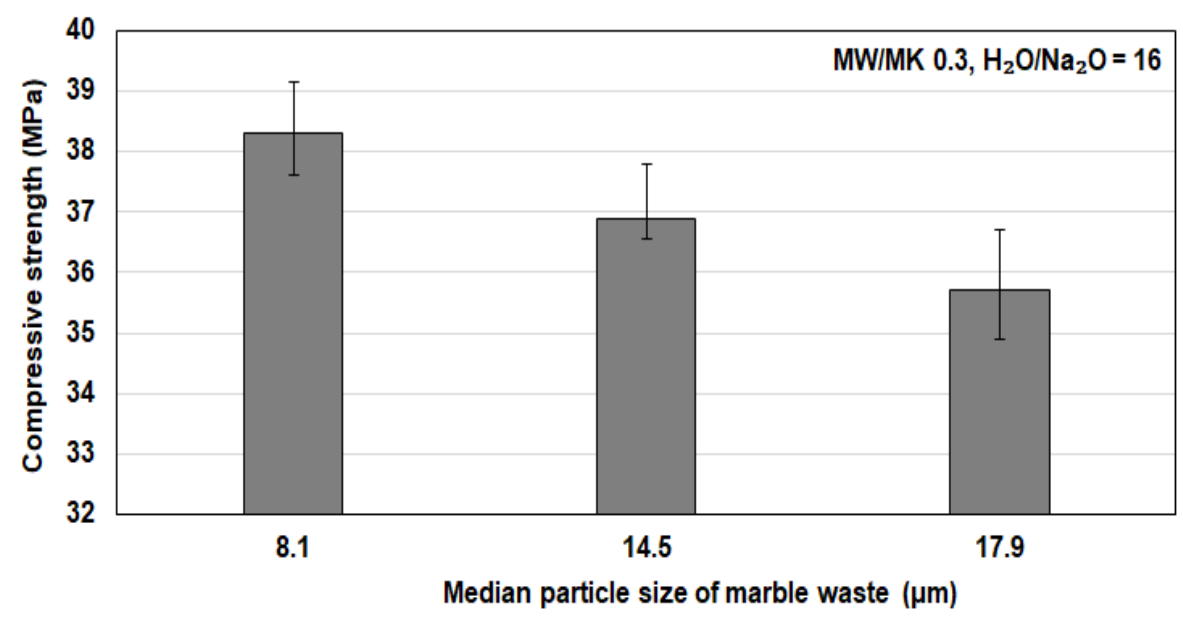

Figure 3. Effect of marble waste median particle size on the 7-day compressive strength of AAMs produced using marble waste to metakaolin mass ratio 0.3 , curing temperature $40{ }^{\circ} \mathrm{C}$ and $\mathrm{H}_{2} \mathrm{O} / \mathrm{Na}_{2} \mathrm{O}$ ratio in the activating solution 16 (the $\mathrm{d}_{90}$ of metakaolin used was quite similar to the respective value of marble waste, $25.5 \mu \mathrm{m})$. 
It is seen from these data that the effect of particle size of marble waste on the compressive strength of the produced AAMs, which varied between 35 and $38 \mathrm{MPa}$, was marginal. It is known from earlier studies that in most cases the decrease in particle size accelerates the rate of alkali activated reactions and results in densification of the matrix of the produced specimens and thus in noticeable increase of the compressive strength. This is due to the increase of the specific surface area of the raw materials and the subsequent increase of their reactivity when attacked by alkali activating solutions $[22,38,42,43]$. However, in our case the close range of the small particle size of both precursors used, which for the marble waste varied between 8.1 and $17.9 \mu \mathrm{m}$, did not affect alkali activation and resulted in the production of AAMs with high compressive strength.

\subsection{Physical Properties of the Produced AAMs}

Table 4 presents the physical properties of selected AAMs prepared from marble waste, metakaolin and their mixture with a marble waste to metakaolin mass ratio 0.3 , using activating solution with $\mathrm{H}_{2} \mathrm{O} / \mathrm{Na}_{2} \mathrm{O}$ molar ratio 16 , after curing at $40{ }^{\circ} \mathrm{C}$ for $24 \mathrm{~h}$. It can be seen from these results that mixing of marble waste with metakaolin has beneficial effect on the properties of the produced AAMs (MW/MK 0.3) when compared to the MW AAM. The porosity and the water absorption dropped by almost $35 \%$ and $50 \%$, compared to the respective values of the reference MW AAMs. On the other hand, their density increased by almost $10 \%$ to $1611 \mathrm{~kg} / \mathrm{m}^{3}$, due to the formation of a dense structure with compressive strength exceeding $35 \mathrm{MPa}$. Furthermore, the porosity and the water absorption of the MW/MK 0.3 AAM increased by $22 \%$ and $26 \%$, while their density decreased by $10 \%$ compared to the respective values of the reference MK AAMs due to the presence of marble powder in the starting mixture.

Table 4. Physical properties of selected AAMs produced with the use of $\mathrm{H}_{2} \mathrm{O} / \mathrm{Na}_{2} \mathrm{O}$ ratio in the activating solution 16 , after curing at $40{ }^{\circ} \mathrm{C}$ for $24 \mathrm{~h}$.

\begin{tabular}{ccccc}
\hline AAM Code & Porosity (\%) & Density $\mathbf{( k g / \mathbf { m } ^ { \mathbf { 3 } } )}$ & Water Absorption (\%) & $\begin{array}{c}\text { Compressive } \\
\text { Strength (MPa) }\end{array}$ \\
\hline MK & 20.6 & 1790 & 11.3 & 40.3 \\
MW & 33.9 & 1483 & 28.7 & 3.9 \\
MW/MK 0.3 & 25.1 & 1611 & 14.2 & 35.7 \\
\hline
\end{tabular}

Table 5 compares the results obtained from this study with those derived from other selected studies investigating the alkali activation of raw material mixtures containing ornamental stone industry waste and metakaolin.

Colangelo et al. [19] produced thermal insulating materials through alkali activation of mixtures containing marble waste, metakaolin and organic additives. Their maximum compressive strength reached was $6 \mathrm{MPa}$, which is considered sufficient for such materials. Clausi et al. [24], prepared AAMs using mixtures of ornamental stones and metakaolin. The produced specimens, after curing for 28 days at $20^{\circ} \mathrm{C}$ and $90 \%$ relative humidity, acquired very high compressive strength values $(72 \mathrm{MPa})$. The $\mathrm{H}_{2} \mathrm{O} / \mathrm{Na}_{2} \mathrm{O}$ molar ratio used in the activating solution was 10, lower than the one used in the present study. Simão et al. [21] used mixtures of marble waste, volcanic stones cutting waste and metakaolin as raw materials to produce inorganic polymers, which after curing at ambient conditions acquired compressive strength of $28.6 \mathrm{MPa}$. The $\mathrm{H}_{2} \mathrm{O} / \mathrm{Na}_{2} \mathrm{O}$ molar ratio in the activating solution was 13, quite similar to the lower one used in the present study.

It is seen from these data that the AAMs produced in the present study acquire compressive strength which is comparable with most values determined in other studies; one noticeable exception is the production of AAMs after alkali activation of ornamental stones which as raw material have more suitable mineralogical composition and thus much higher alkali activation potential compared to marble waste. 
Table 5. Comparison of synthesis conditions and compressive strength values for ornamental stone industry waste and metakaolin-based AAMs.

\begin{tabular}{ccccc}
\hline Raw Materials & $\begin{array}{c}\mathbf{H}_{2} \mathbf{O} / \mathrm{Na}_{2} \mathbf{O} \\
\text { Molar Ratio }\end{array}$ & Curing Conditions & $\begin{array}{c}\text { Compressive } \\
\text { Strength (Mpa) }\end{array}$ & References \\
\hline $\begin{array}{c}\text { Marble waste, } \\
\text { metakaolin, epoxy } \\
\text { resin, expanded } \\
\text { polystyrene }\end{array}$ & 11.0 & $40{ }^{\circ} \mathrm{C}, 24 \mathrm{~h}$ & 6.0 & [19] \\
$\begin{array}{c}\text { Ornamental stones, } \\
\text { metakaolin, standard } \\
\text { siliceous sand }\end{array}$ & 10.0 & $\begin{array}{c}20{ }^{\circ} \mathrm{C}, 90 \% \text { relative } \\
\text { humidity, } 28 \text { days }\end{array}$ & 72.0 & [24] \\
$\begin{array}{c}\text { Marble and volcanic } \\
\text { stones cutting waste, } \\
\text { metakaolin } \\
\text { Marble waste, } \\
\text { metakaolin }\end{array}$ & 13.0 & $\begin{array}{c}\text { Room temperature, } \\
28 \text { days }\end{array}$ & 28.6 & This study \\
\hline
\end{tabular}

\subsection{Morphology of Selected AAMs \\ 3.5.1. Mineralogical Analysis}

The mineralogy of the raw materials, the AAMs produced (MW/MK 0.3) under the optimum conditions (marble waste to metakaolin mass ratio $0.3, \mathrm{H}_{2} \mathrm{O} / \mathrm{Na}_{2} \mathrm{O}$ molar ratio 16 , curing temperature $40^{\circ} \mathrm{C}$ ), as well as of the reference MW or MK AAMs, is shown in the XRD patterns presented in Figure 4.

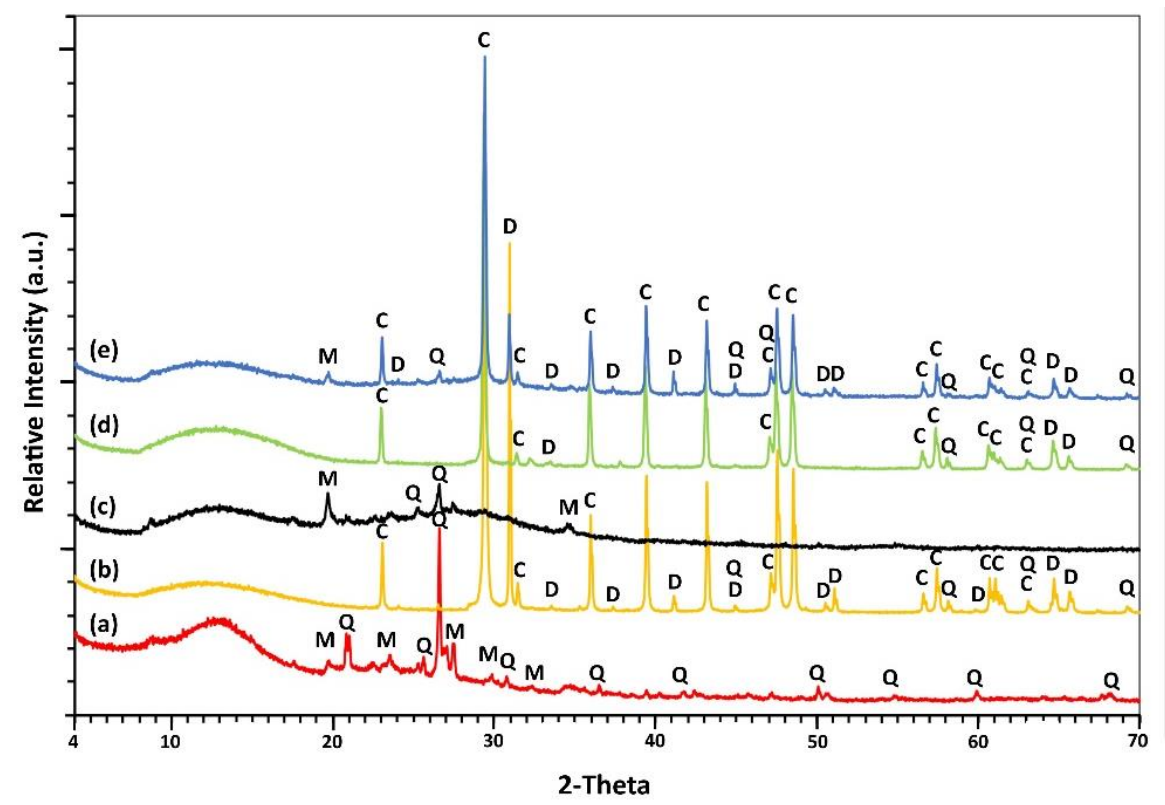

Figure 4. X-ray diffractograms of the raw materials (a) metakaolin, (b) marble waste, and the AAMs (c) MK, (d) MW, and (e) $\mathrm{MW} / \mathrm{MK} 0.3$, produced under the optimum conditions $\left(\mathrm{H}_{2} \mathrm{O} / \mathrm{Na}_{2} \mathrm{O}\right.$ molar ratio 16 , curing temperature $\left.40^{\circ} \mathrm{C}\right)$. Identification of phases: $\mathrm{C}$ : Calcite $\left(\mathrm{CaCO}_{3}\right)$, D: Dolomite $\left[\mathrm{CaMg}\left(\mathrm{CO}_{3}\right)_{2}\right]$, Q: Quartz $\left(\mathrm{SiO}_{2}\right)$ and M: Muscovite $\left[\mathrm{KAl}_{2}\left(\mathrm{AlSi}_{3} \mathrm{O}_{10}\right)(\mathrm{OH})_{2}\right]$.

The main mineralogical phases present in the XRD patterns of metakaolin (Figure 4a) as well as of the respective reference AAM (MK) (Figure 4c) are quartz and muscovite. On the other hand, the patterns of marble waste (Figure $4 \mathrm{~b}$ ) and the respective reference AAM (MW) (Figure 4d) exhibit a crystalline structure which mainly consists of calcite, dolomite and quartz.

The pattern of the MK AAM (Figure 4c) also exhibits a slight hump around 25-30 (2-theta) which is indicative of amorphicity [21,40], while the AAMs produced from a 
marble waste to metakaolin mass ratio 0.3 (MW/MK 0.3 AAM, Figure 4e) contain crystalline phases which exhibit lower intensity compared to the respective ones present in the raw materials. Overall, it can be seen that the peak intensities of the crystalline phases of calcite, dolomite, muscovite and quartz present in the produced AAMs decreased or even disappeared compared to the ones present in the raw materials (waste marble and metakaolin). The decreasing intensities of these phases which identified in all AAMs (MK, MW and MW/MK) indicate their dissolution in the polymeric matrix due to the attack of the alkali activator and the subsequent formation of aluminosilicate amorphous gels, as shown by the following SEM-EDS analysis.

\subsubsection{FTIR Analysis}

Figure 5 illustrates the FTIR spectra of the raw materials (marble waste and metakaolin), as well as of the AAMs (MW, MK, and MW/MK 0.3) produced under the optimum conditions $\left(\mathrm{H}_{2} \mathrm{O} / \mathrm{Na}_{2} \mathrm{O}\right.$ molar ratio 16 , curing at $40{ }^{\circ} \mathrm{C}$ for $\left.24 \mathrm{~h}\right)$.

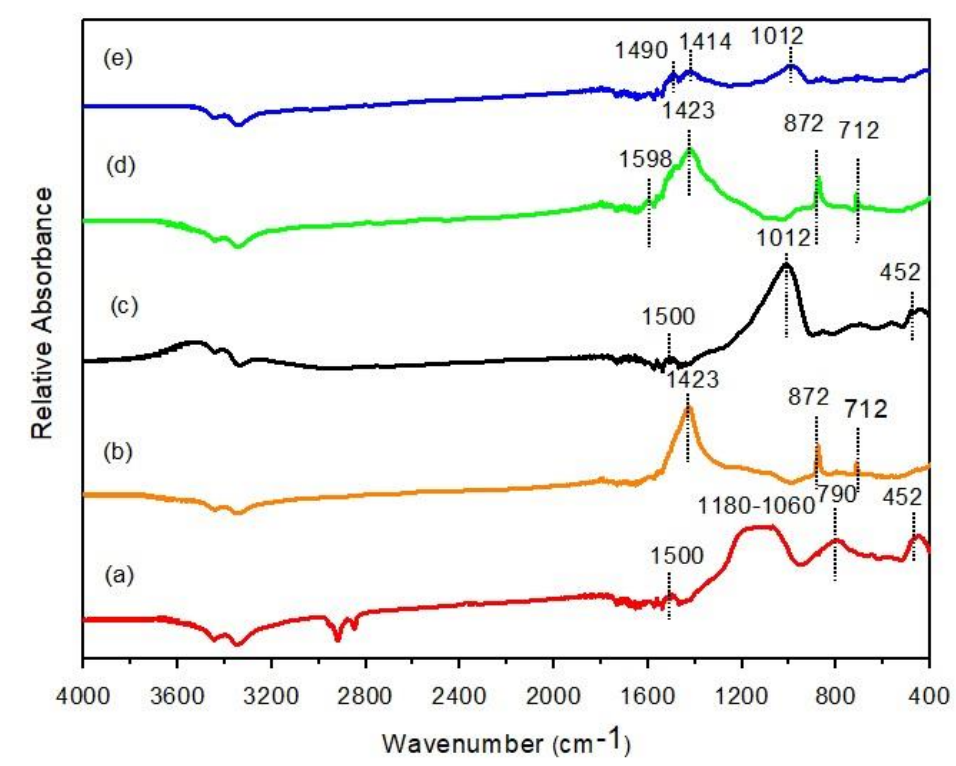

Figure 5. Fourier Transform Infrared Spectroscopy (FTIR) spectra of the raw materials (a) metakaolin, (b) marble waste, and the AAMs (c) MK, (d) MW, and (e) MW/MK 0.3, produced under the optimum conditions $\left(\mathrm{H}_{2} \mathrm{O} / \mathrm{Na}_{2} \mathrm{O}\right.$ molar ratio 16 , curing temperature $40{ }^{\circ} \mathrm{C}$, curing period $\left.24 \mathrm{~h}\right)$.

The spectrum of raw metakaolin is shown in Figure $5 \mathrm{a}$. The peaks seen at $452 \mathrm{~cm}^{-1}$ and $790 \mathrm{~cm}^{-1}$ are related to Al-O-Si bonds, while the broad band illustrated between $1180-1060 \mathrm{~cm}^{-1}$ denotes its aluminosilicate matrix [36]. As seen in the spectrum of MK AAM (Figure 5c), the peak illustrated at $790 \mathrm{~cm}^{-1}$ in the raw material almost disappeared. This is attributed to the development of the aluminosilicate network due to alkali activation [39]. The peak seen at $1012 \mathrm{~cm}^{-1}$, also shown in the MW / MK 0.3 AAM (Figure 5e), corresponds to Si-O-Si and Al-O-Si asymmetrical stretching vibrations due to the $\mathrm{SiO}_{4}$ and $\mathrm{AlO}_{4}$ reorganization that took place during alkali activation $[37,44]$.

The spectra of raw marble waste (Figure 5b) and MW AAM (Figure 5d) did not show any considerable changes, indicating that marble waste is poorly alkali activated. The bands at 712,872 and $1423 \mathrm{~cm}^{-1}$, illustrated in both spectra represent $\mathrm{CO}_{3}$ vibrations due to the presence of $\mathrm{CaCO}_{3}[45,46]$. In the spectrum of the MW/MK 0.3 AAM (Figure 5e) the peaks at 1414 and $1490 \mathrm{~cm}^{-1}$ are due to atmospheric carbonation [47]. The band seen at $1500 \mathrm{~cm}^{-1}$ corresponds to H-O-H vibrations of absorbed water, while the peak at $1598 \mathrm{~cm}^{-1}$ is due to the presence of chemically bonded water [48]. 


\subsubsection{SEM Analysis}

Figure 6 shows the SEM images of selected AAMs (MW, MW/MK 0.3 and MK) produced under the optimum conditions $\left(\mathrm{H}_{2} \mathrm{O} / \mathrm{Na}_{2} \mathrm{O}\right.$ molar ratio 16 , curing at $40{ }^{\circ} \mathrm{C}$ for $\left.24 \mathrm{~h}\right)$. SEM examination of MW AAM surface and microanalysis by EDS (Figure $6 a, b$ ) revealed an heterogeneous in size microstructure that is dominated by large calcite crystals $(>30 \mu \mathrm{m}$ long) along with smaller crystals $(<15 \mu \mathrm{m})$ of dolomite. In higher magnification (Figure $6 \mathrm{~b}$ ), it is shown that the microstructure of the MW AAM is loose and several undissolved/unhydrated particles of various sizes and sharp edges as well as large voids (black gaps) are detected; this indicates their limited reaction during alkali activation due to the low reactivity of marble waste precursor, as results from its low inherent content of silica and alumina. The large number of voids and un-reacted particles indicates poor structural integrity that negatively affects the compressive strength of the produced AAM (3.9 MPa).
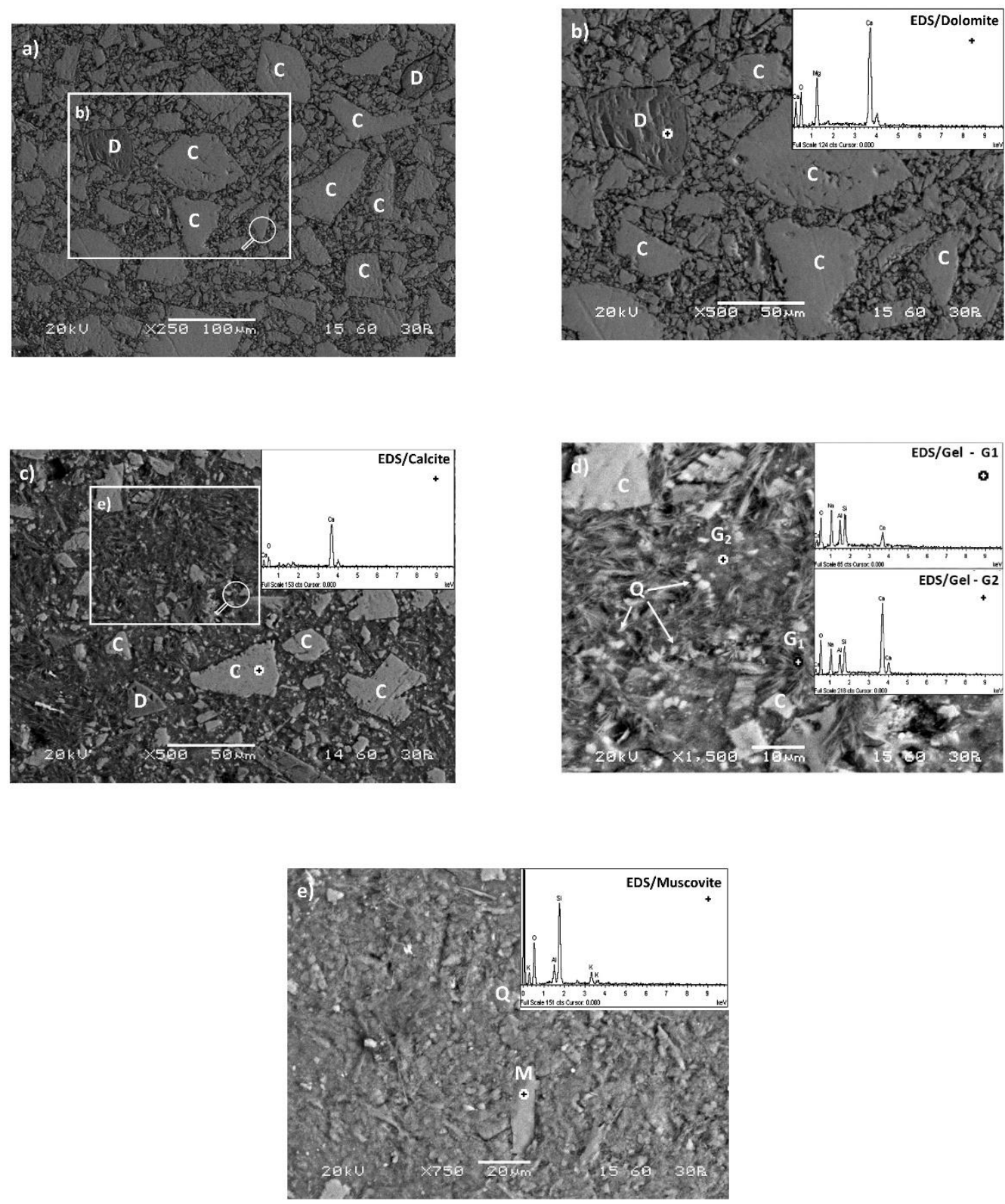

Figure 6. SEM-BSE images of polished cross-sections of selected AAMs produced under the optimum conditions $\left(\mathrm{H}_{2} \mathrm{O} / \mathrm{Na}_{2} \mathrm{O}\right.$ molar ratio 16, curing at $40{ }^{\circ} \mathrm{C}$ for $\left.24 \mathrm{~h}\right)$ : (a,b) $\mathrm{MW}$, (c,d) MW/MK 0.3 and (e) MK. EDS spectra show in several spot locations the presence of oxide phases, the formation of mixed aggregates and newly formed inorganic gels (C: Calcite, D: Dolomite, M: Muscovite, Q: Quartz, G 1 :Gel Na-rich, $\mathrm{G}_{2}$ : Gel Ca-rich). 
On the other hand, the microstructure of the MW/MK 0.3 and MK AAMs is mainly characterized by smaller particles and the formation of a more homogenous polymeric network with less visible cracks compared to MW AAM (Figure 6c,d and e, respectively). However, the MK AAM is characterized by a more homogeneous and compact microstructure due to the formation of a denser matrix in which very few unreactive particles are seen; this is due to the presence of metakaolin and the resulting higher degree of polymerization (Figure 6e). Figure 6d (zoom of rectangular area of Figure 6c) shows an improved pore refinement in the entire matrix of the MW/MK 0.3 AAM compared to MW AAM, due to the addition of metakaolin as precursor in the starting mixture, as well as fewer smaller in size unreactive particles that exhibit better cohesion with the precursors; this dense and compact microstructure justifies the high compressive strength obtained by the MW/MK 0.3 AAM (35.7 MPa) which is slightly lower in comparison to MK AAM (40.3. MPa) (Table 3).

The well-formed microstructure of the MW/MK 0.3 AAM was further evaluated using quantitative EDS analysis in order to elucidate the formation of the hydrated products in the polymeric matrix. SEM-EDS analyses confirmed the excessive formation of two types of gels i.e., a needle-like N-A-S-H $\left(G_{1}\right)$ and a continuous flake-like $(\mathrm{N}, \mathrm{C})-\mathrm{A}-\mathrm{S}-\mathrm{H}\left(\mathrm{G}_{2}\right)$ shown in Figure 6d. More specifically, EDS analyses indicate the formation of a N-A-S-H gel rich in $\mathrm{Na}$ and $\mathrm{Al}$ and poor in $\mathrm{Ca}$ with $\mathrm{Al} / \mathrm{Si}, \mathrm{Na} / \mathrm{Si}$ and $\mathrm{Ca} / \mathrm{Si}$ ratios equal to $0.38,0.82$ and 0.14 , respectively. As the polycondensation reactions progress, Ca ions dissolve from the Ca-rich marble waste and replace $\mathrm{Na}$ ions in the N-A-S-H gel via an ion exchange process that consequently result in the formation of the solid (N,C)-A-S-H gel [49]. Although both gels are characterized by similar $\mathrm{Al} / \mathrm{Si}$ ratio (0.35) due to the addition of metakaolin in the starting mixture, small amount of $\mathrm{Na}$ and big amount of $\mathrm{Ca}$ incorporated in the (N,C)-A-S$\mathrm{H}$ gel, as indicated by the corresponding $\mathrm{Na} / \mathrm{Si}$ (0.21) and $\mathrm{Ca} / \mathrm{Si}$ (1.6) ratios, respectively. The co-existence of these two types of gels in the structure of the MW/MK 0.3 AAM is the major strength contributor and justifies its good mechanical properties [5,50].

In other related studies, it has been mentioned that during alkali activation some of the unreacted $\mathrm{CaCO}_{3}$, which is the major constituent of marble waste, may induce a micro-filler effect in the AAMs produced when marble waste and aluminosilicate minerals are used as precursors [51]. On the other hand, it has been mentioned that $\mathrm{CaCO}_{3}$ exhibits rather reduced solubility in alkaline solutions [52]. However, some precipitation of C-A-S-H and $\mathrm{N}-\mathrm{A}-\mathrm{S}-\mathrm{H}$ phases may take place during alkali activation and result in the increase of the compressive strength of the produced specimens $[53,54]$. In another recent study it was shown that the incorporation of cotton and viscon fibers improved the microstructure and properties of geopolymer concrete produced from zeolitic tuff and marble waste [55]. Therefore, the final microstructure of the alkali activated materials may be the result of the synergistic action of the filler effect and the precipitation of calcium bearing phases.

\subsection{Structural Integrity}

The durability of the MW/MK 0.3 AAM produced under the optimum conditions (marble waste to metakaolin mass ratio $0.3, \mathrm{H}_{2} \mathrm{O} / \mathrm{Na}_{2} \mathrm{O}$ molar ratio 16 , curing at $40{ }^{\circ} \mathrm{C}$ for $24 \mathrm{~h}$ ) was tested after exposure in different aggressive environments, namely firing at 200, 400 and $600{ }^{\circ} \mathrm{C}$ for $2 \mathrm{~h}$, immersion in deionized water and $1 \mathrm{~mol} / \mathrm{L} \mathrm{NaCl}$ solution for 7 and 30 days, and also implementation of freeze-thaw cycles according to ASTM C1262-10.

Table 6 shows the evolution of compressive strength and weight loss of the MW/MK 0.3 AAM after firing at 200, 400 and $600{ }^{\circ} \mathrm{C}$ for $2 \mathrm{~h}$. It is seen from these data that the AAM lost a substantial percentage of its compressive strength, even after firing at $200{ }^{\circ} \mathrm{C}$ which is considered a low temperature, while after firing at temperatures higher than $400{ }^{\circ} \mathrm{C}$ it almost disintegrated. The weight loss increased, in accordance with the loss of compressive strength, from $24.6 \%$ at $200{ }^{\circ} \mathrm{C}$ to $33.5 \%$ at $600{ }^{\circ} \mathrm{C}$. The detrimental effect of high-temperature firing on the integrity of the AAM is attributed to the decomposition of aluminosilicate bonds, the loss of water as well as the development and subsequent propagation of cracks. The behavior of the AAM after firing, as determined in this study, 
was worse compared to the behavior of AAMs produced from other waste types, including slags or construction and demolition wastes [56,57].

Table 6. Compressive strength and weight loss of the MW/MK 0.3 AAM (marble waste to metakaolin mass ratio $0.3, \mathrm{H}_{2} \mathrm{O} / \mathrm{Na}_{2} \mathrm{O}$ molar ratio 16 , curing at $40{ }^{\circ} \mathrm{C}$ for $24 \mathrm{~h}$ ) after firing at different temperatures.

\begin{tabular}{ccc}
\hline Temperature $\left({ }^{\circ} \mathbf{C}\right)$ & Compressive Strength $(\mathbf{M P a})$ & Weight Loss $(\%)$ \\
\hline 40 & 35.7 & - \\
200 & 16.2 & 24.6 \\
400 & 7.5 & 28.4 \\
600 & 1.6 & 33.5 \\
\hline
\end{tabular}

Figure 7 shows the evolution of the compressive strength and weight loss of the $\mathrm{MW} / \mathrm{MK} 0.3$ AAM after immersion in deionized water and $1 \mathrm{~mol} / \mathrm{L} \mathrm{NaCl}$ solution for 7 and 30 days.

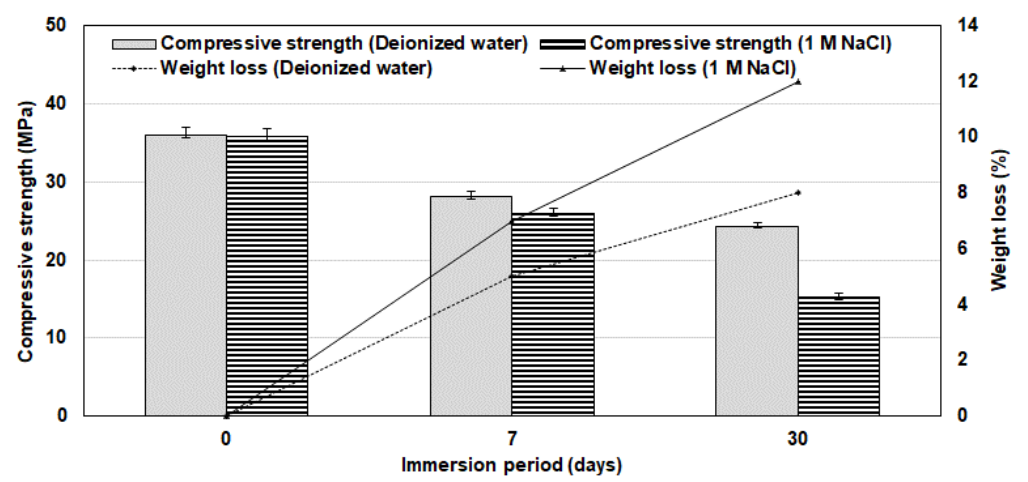

Figure 7. Evolution of compressive strength and weight loss of MW/MK 0.3 AAM after immersion in deionized water and $1 \mathrm{~mol} / \mathrm{L} \mathrm{NaCl}$ solution for 7 and 30 days.

As seen in Figure 7, the MW/MK 0.3 AAM after immersion in $1 \mathrm{~mol} / \mathrm{L} \mathrm{NaCl}$ solution for 30 days exhibited the highest compressive strength loss $(58 \%)$ due to the disintegration of the Si-O-Al-Si bonds [56,58]. On the other hand, after immersion in deionized water for the same period it retained an acceptable compressive strength level (24.3 MPa). Immersion for a period of 7 days in both deionized water and $\mathrm{NaCl}$ solution had a milder impact on the compressive strength and the determined values varied between 25 and $28 \mathrm{MPa}$. As also anticipated, immersion in $1 \mathrm{~mol} / \mathrm{L} \mathrm{NaCl}$ solution over a period of 30 days resulted in the highest weight loss $(12 \%)$, while immersion in deionized water for the same period caused lower weight loss $(8 \%)$.

Figure 8 shows the behavior of the MW / MK 0.3 after subjection to freeze-thaw cycles according to ASTM C1262-10 standard. It can be seen from these data that the AAM exhibited very low resistance, by taking into account that the compressive strength loss after 7 freeze-thaw cycles was close to $40 \%$, while after 15 cycles it increased to values higher than $60 \%$. It is mentioned that the weight loss of the MW/MK 0.3 AAM after 7 and 15 freeze-thaw cycles was also high, namely 17 and 39\%, respectively.

The poor performance of the AAM is due to its properties (Table 4) and particularly its high porosity (25.1\%) and water absorption (14.2\%). The main deterioration mechanism is the freezing of the water absorbed by the capillaries which results in the development and subsequent expansion of cracks [59]. The behavior of the AAM after subjection to more than 15 freeze-thaw cycles could not be evaluated, since its structural integrity was severely affected (Figure 9). 


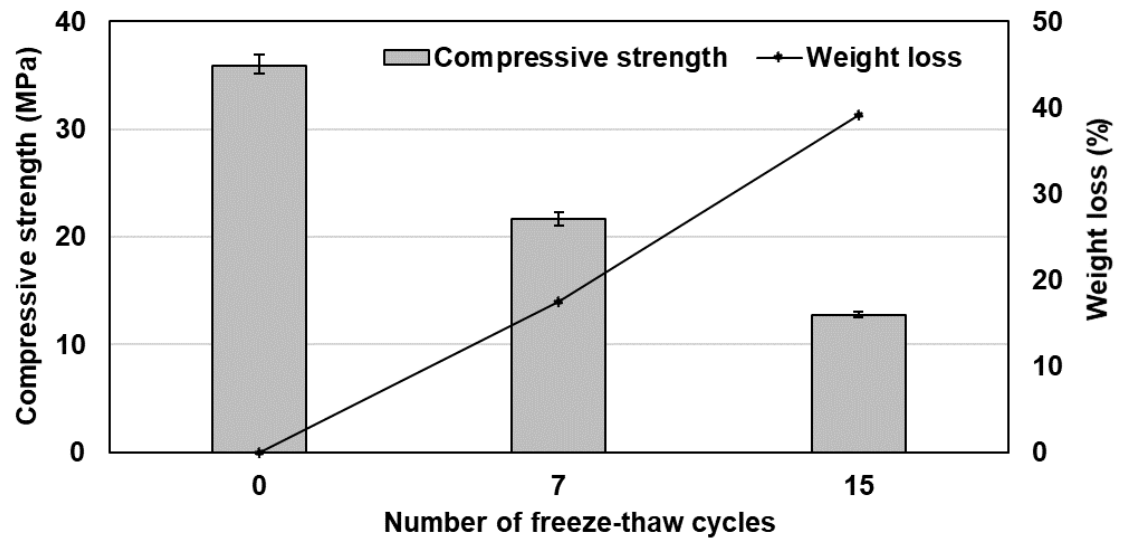

Figure 8. Compressive strength and weight loss of the MW/MK 0.3 AAM after subjection to 7 and 15 freeze-thaw cycles according to ASTM C1262-10.

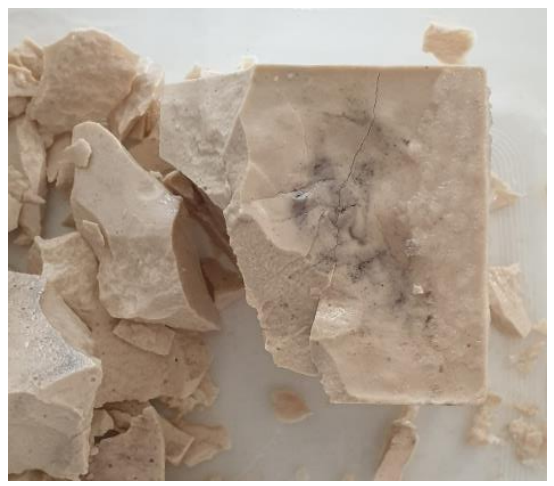

Figure 9. Photo showing the structural deterioration of the MW/MK 0.3 AAM after subjection to 15 freeze-thaw cycles.

Based on the evaluation of the results of the present study, it is deduced that the best AAMs obtained, e.g., MW/MK 0.3, may be used as alternative binders which exhibit good mechanical and physico-chemical properties which are similar to those of ordinary Portland cement. Thus, the production of alkali activated materials from marble wastes amended with metakaolin offers significant environmental and economic advantages and results in the valorization of this large waste stream which is usually disposed to the environment and causes several impacts $[14,60]$.

\section{Conclusions}

This study showed that marble waste can be valorized, with the addition of metakaolin, via alkali activation for the production of AAMs with beneficial physical and mechanical properties. The highest compressive strength was obtained by the AAMs produced when marble waste was mixed with metakaolin at a ratio of 0.3 and alkali activated under the optimum synthesis conditions, namely $\mathrm{H}_{2} \mathrm{O} / \mathrm{Na}_{2} \mathrm{O}$ molar ratio 16 in the activating solution, curing temperature $40^{\circ} \mathrm{C}$, curing time $24 \mathrm{~h}$ and ageing time 7 days.

The addition of metakaolin as precursor during alkali activation was considered due to its known high alkali activation potential. The properties and the microstructure of MW/MK AAMs are mainly due to the synergistic action of the filler effect of calcium carbonate present in marble waste and the precipitation of some calcium bearing phases.

The produced AAMs showed a fairly good performance after immersion in $1 \mathrm{~mol} / \mathrm{L}$ $\mathrm{NaCl}$ solution and especially in deionized water. More specifically, the AAMs after immersion in deionized water for 30 days retained an acceptable compressive strength value (24.3 MPa). On the other hand, when the AAMs subjected to firing at $200{ }^{\circ} \mathrm{C}$ they lost 
a substantial percentage of their compressive strength while after firing at temperatures higher than $400{ }^{\circ} \mathrm{C}$ their integrity was deteriorated fast.

In addition, the structural integrity of the produced AAMs was severely affected after subjection to freeze-thaw tests, and the compressive strength loss after 7 cycles reached almost the value of $40 \%$. This is attributed to the high porosity $(25.1 \%)$ and water absorption $(14.2 \%)$ values of the initial specimens.

Additional studies are under way to improve alkali activation of marble waste and maximize its valorization potential. These studies explore the use of other precursors including mixtures of marble waste and other waste types with much higher $\mathrm{Si}$ and $\mathrm{Al}$ content which exhibit higher alkali activation potential, such as metallurgical slags or construction and demolition wastes, to improve the properties of the produced AAMs. Substitution of metakaolin with other precursors may result in a process with reduced cost and also enable the valorization of other waste streams that are produced worldwide in very large quantities. Also, the incorporation of natural fibers in the AAMs produced after alkali activation may result in specimens with beneficial properties. In any case, the selection of an additive that will improve the alkali activation potential of marble wastes depends on the desired properties of the produced specimens that define their final use as for example binder or construction element exhibiting among others suitable compressive strength, porosity or fire resistance.

Author Contributions: K.K. conceived of the idea, designed the experiments, analyzed the results and reviewed the paper. A.S. performed the experiments, analyzed the results and wrote the first draft of the paper, G.B. carried out SEM studies and reviewed the mineralogical part of the paper. All authors have read and agreed to the published version of the manuscript.

Funding: This research was funded by the project "INVALOR: Research Infrastructure for Waste Valorization and Sustainable Management" (MIS 5002495), which is implemented under the Action "Reinforcement of the Research and Innovation Infrastructure," funded by the operational program "Competitiveness, Entrepreneurship and Innovation" (NSRF 2014-2020) and co-financed by Greece and the European Union (European Regional Development Fund).

Institutional Review Board Statement: Not applicable.

Informed Consent Statement: Not applicable.

Data Availability Statement: The data presented in this study are available on request from the corresponding author. The data are not publicly available yet, due to the fact that the final report of the project INVALOR has not been submitted.

Acknowledgments: The authors wish to express their sincere thanks to the three anonymous reviewers for their constructive comments, which significantly improved the quality of the paper.

Conflicts of Interest: The authors declare no conflict of interest.

\section{References}

1. Demirel, B.; Alyamaç, K.E. Waste and Supplementary Cementitious Materials in Concrete: Characterization, Properties and Applications, 1st ed.; Woodhead Publishing: Cambridge/Sawston, UK, 2018; pp. 181-197.

2. Kore, S.D.; Vyas, A.K. Impact of marble waste as coarse aggregate on properties of lean cement concrete. Case Stud. Constr. Mater. 2016, 4, 85-92. [CrossRef]

3. Lee, W.H.; Lin, K.L.; Chang, T.H.; Ding, Y.C.; Cheng, T.W. Sustainable development and performance evaluation of marble-wastebased geopolymer concrete. Polymers 2020, 12, 1924. [CrossRef] [PubMed]

4. Altun, N.E. Assessment of marble waste utilization as an alternative sorbent to limestone for $\mathrm{SO}_{2}$ control. Fuel Process. Technol. 2014, 128, 461-470. [CrossRef]

5. Tekin, I. Properties of $\mathrm{NaOH}$ activated geopolymer with marble, travertine and volcanic tuff wastes. Constr. Build. Mater. 2016, 127, 607-617. [CrossRef]

6. Thakur, A.K.; Pappu, A.; Thakur, V.K. Synthesis and characterization of new class of geopolymer hybrid composite materials from industrial wastes. J. Clean. Prod. 2019, 230, 11-20. [CrossRef]

7. Hebhoub, H.; Aoun, H.; Belachia, M.; Houari, H.; Ghorbel, E. Use of waste marble aggregates in concrete. Constr. Build. Mater. 2011, 25, 1167-1171. [CrossRef]

8. Saboya, F., Jr.; Xavier, G.C.; Alexandre, J. The use of the powder marble by-product to enhance the properties of brick ceramic. Constr. Build. Mater. 2007, 21, 1950-1960. [CrossRef] 
9. Khan, Z.; Umar, M.; Shahzada, S.; Arshad, A. Utilization of marble dust in fired clay bricks. J. Environ. Monit. 2017, 17, 4-10.

10. Galetakis, M.; Soultana, A. A review on the utilization of quarry and ornamental stone industry fine by-products in the construction sector. Constr. Build. Mater. 2016, 102, 769-781. [CrossRef]

11. Davidovits, J. Geopolymers-Inorganic polymeric new materials. J. Therm. Anal. Calorim. 1991, 37, 1633-1656. [CrossRef]

12. Komnitsas, K.; Zaharaki, D.; Perdikatsis, V. Effect of synthesis parameters on the compressive strength of low-calcium ferronickel slag inorganic polymers. J. Hazard. Mater. 2009, 161, 760-768. [CrossRef] [PubMed]

13. Komnitsas, K. Potential of geopolymer technology towards green buildings and sustainable cities. Procedia Eng. 2011, 21, 1023-1032. [CrossRef]

14. Luukkonen, T.; Abdollahnejad, Z.; Yliniemi, J.; Kinnunen, P.; Illikainen, M. One-part alkali-activated materials: A review. Cem. Concr. Res. 2018, 103, 21-34. [CrossRef]

15. Komnitsas, K.; Bartzas, G.; Karmali, V.; Petrakis, E.; Kurylak, W.; Pietek, G.; Kanasiewicz, J. Assessment of alkali activation potential of a Polish ferronickel slag. Sustainability 2019, 11, 1863. [CrossRef]

16. Mohajerani, A.; Suter, D.; Jeffrey-Bailey, T.; Song, T.; Arulrajah, A.; Horpibulsuk, S.; Law, D. Recycling waste materials in geopolymer concrete. Clean Technol. Environ. Policy 2019, 21, 493-515. [CrossRef]

17. Komnitsas, K.; Yurramendi, L.; Bartzas, G.; Karmali, V.; Petrakis, E. Factors affecting co-valorization of fayalitic and ferronickel slags for the production of alkali activated materials. Sci. Total Environ. 2020, 721, 137753. [CrossRef]

18. Wang, Q.; Ding, Z.Y.; Da, J.; Ran, K.; Sui, Z.T. Factors influencing bonding strength of geopolymer-aggregate interfacial transition zone. Adv. Mat. Res. 2011, 224, 1-7. [CrossRef]

19. Colangelo, F.; Roviello, G.; Ricciotti, L.; Ferrándiz-Mas, V.; Messina, F.; Ferone, C.; Cheeseman, C.R. Mechanical and thermal properties of lightweight geopolymer composites. Cem. Concr. Compos. 2018, 86, 266-272. [CrossRef]

20. Coppola, B.; Palmero, P.; Montanaro, L.; Tulliani, J.M. Alkali-activation of marble sludge: Influence of curing conditions and waste glass addition. J. Eur. Ceram. Soc. 2020, 40, 3776-3787. [CrossRef]

21. Simão, L.; Hotza, D.; Ribeiro, M.J.; Novais, R.M.; Montedo, O.R.K.; Raupp-Pereira, F. Development of new geopolymers based on stone cutting waste. Constr. Build. Mater. 2020, 257, 119525. [CrossRef]

22. Petrakis, E.; Karmali, V.; Bartzas, G.; Komnitsas, K. Grinding kinetics of slag and effect of final particle size on the compressive strength of alkali activated materials. Minerals 2019, 9, 714. [CrossRef]

23. Aughenbaugh, K.L.; Williamson, T.; Juenger, M.C.G. Critical evaluation of strength prediction methods for alkali-activated fly ash. Mater. Struct. 2015, 48, 607-620. [CrossRef]

24. Clausi, M.; Tarantino, S.C.; Magnani, L.L.; Riccardi, M.P.; Tedeschi, C.; Zema, M. Metakaolin as a precursor of materials for applications in Cultural Heritage: Geopolymer-based mortars with ornamental stone aggregates. Appl. Clay Sci. 2016, 132, 589-599. [CrossRef]

25. BS EN 1936:2006. Natural Stone Test Methods. Determination of Real Density and Apparent Density, and of Total and Open Porosity; British Standards Institution: London, UK, 2006; Available online: https: / / shop.bsigroup.com/ProductDetail/?pid=000000000030149240 (accessed on 8 April 2020).

26. BS EN 13755:2008. Natural Stone Test Methods. Determination of Water Absorption at Atmospheric Pressure; British Standards Institution: London, UK, 2006; Available online: https://shop.bsigroup.com/ProductDetail/?pid=000000000030163234 (accessed on 8 April 2020).

27. ASTM C1262-10. Standard Test Method for Evaluating the Freeze-Thaw Durability of Dry-Cast Segmental Retaining Wall Units and Related Concrete Units; ASTM International: West Conshohocken, PA, USA, 2010; Available online: https://www.astm.org/ DATABASE.CART/HISTORICAL/C1262-10.htm (accessed on 6 April 2020).

28. Bernal, S.A. Effect of the activator dose on the compressive strength and accelerated carbonation resistance of alkali silicateactivated slag/metakaolin blended materials. Constr. Build. Mater. 2015, 98, 217-226. [CrossRef]

29. Samson, G.; Cyr, M.; Gao, X.X. Formulation and characterization of blended alkali-activated materials based on flash-calcined metakaolin, fly ash and GGBS. Constr. Build. Mater. 2017, 144, 50-64. [CrossRef]

30. Jin, M.; Lian, F.; Xia, R.; Wang, Z. Formulation and durability of a geopolymer based on metakaolin/tannery sludge. Waste Manag. 2018, 79, 717-728. [CrossRef]

31. Liang, G.; Zhu, H.; Zhang, Z.; Wu, Q.; Du, J. Investigation of the waterproof property of alkali-activated metakaolin geopolymer added with rice husk ash. J. Clean. Prod. 2019, 230, 603-612. [CrossRef]

32. Perez-Cortes, P.; Escalante-Garcia, J.I. Alkali activated metakaolin with high limestone contents - Statistical modeling of strength and environmental and cost analyses. Cem. Concr. Compos. 2020, 106, 103450. [CrossRef]

33. Sarkar, M.; Dana, K. Partial replacement of metakaolin with red ceramic waste in geopolymer. Ceram. Int. 2020. [CrossRef]

34. Liu, J.; Hu, L.; Tang, L.; Ren, J. Utilisation of municipal solid waste incinerator (MSWI) fly ash with metakaolin for preparation of alkali-activated cementitious material. J. Hazard. Mater. 2021, 402, 123451. [CrossRef]

35. Zaharaki, D.; Komnitsas, K.; Perdikatsis, V. Use of analytical techniques for identification of inorganic polymer gel composition. J. Mater. Sci. 2010, 45, 2715-2724. [CrossRef]

36. Gado, R.A.; Hebda, M.; Łach, M.; Mikuła, J. Alkali activation of waste clay bricks: Influence of the silica modulus, $\mathrm{SiO}_{2} / \mathrm{Na}_{2} \mathrm{O}$, $\mathrm{H}_{2} \mathrm{O} / \mathrm{Na}_{2} \mathrm{O}$ molar ratio, and liquid/solid ratio. Materials 2020, 13, 383. [CrossRef] [PubMed]

37. Soultana, A.; Valouma, A.; Bartzas, G.; Komnitsas, K. Properties of inorganic polymers produced from brick waste and metallurgical slag. Minerals 2019, 9, 551. [CrossRef] 
38. Bing-hui, M.; Zhu, H.; Xue-min, C.; Yan, H.; Si-yu, G. Effect of curing temperature on geopolymerization of metakaolin-based geopolymers. Appl. Clay Sci. 2014, 99, 144-148.

39. Chen, L.; Wang, Z.; Wang, Y.; Feng, J. Preparation and properties of alkali activated metakaolin-based geopolymer. Materials 2016, 9, 767. [CrossRef] [PubMed]

40. Mahmoodi, O.; Siad, H.; Lachemi, M.; Dadsetan, S.; Sahmaran, M. Development of normal and very high strength geopolymer binders based on concrete waste at ambient environment. J. Clean. Prod. 2020, 279, 123436. [CrossRef]

41. Provis, J.L.; Arbi, K.; Bernal, S.A.; Bondar, D.; Buchwald, A.; Castel, A.; Chithiraputhiran, S.; Cyr, M.; Dehghan, A.; DombrowskiDaube, K.; et al. RILEM TC 247-DTA round robin test: Mix design and reproducibility of compressive strength of alkali-activated concretes. Mater. Struct. 2019, 52, 99. [CrossRef]

42. Komnitsas, K.; Zaharaki, D.; Vlachou, A.; Bartzas, G.; Galetakis, M. Effect of synthesis parameters on the quality of construction and demolition wastes (CDW) geopolymers. Adv. Powder Technol. 2015, 26, 368-376. [CrossRef]

43. Vogt, O.; Ukrainczyk, N.; Ballschmiede, C.; Koenders, E. Reactivity and Microstructure of Metakaolin Based Geopolymers: Effect of Fly Ash and Liquid/Solid Contents. Materials 2019, 12, 3485. [CrossRef]

44. Tan, Q.W.; Li, N.; Xu, Z.H.; Chen, X.Y.; Peng, X.; Shuai, Q.; Yao, Z.Z. Comparative performance of cement and metakaolin based-geopolymer blocks for strontium immobilization. J. Ceram. Soc. Jpn. 2019, 127, 44-49. [CrossRef]

45. Król, M.; Minkiewicz, J.; Mozgawa, W. IR spectroscopy studies of zeolites in geopolymeric materials derived from kaolinite. J. Mol. Struct. 2016, 1126, 200-206. [CrossRef]

46. Zapata, P.A.; Palza, H.; Díaz, B.; Armijo, A.; Sepúlveda, F.; Ortiz, J.A.; Ramírez, M.P.; Oyarzún, C. Effect of CaCO 3 nanoparticles on the mechanical and photo-degradation properties of LDPE. Molecules 2018, 24, 126. [CrossRef] [PubMed]

47. Beleuk à Moungam, L.; Mohamed, H.; Kamseu, E.; Billong, N.; Melo, U. Properties of geopolymers made from fired clay bricks wastes and rice husk ash (RHA)-Sodium hydroxide (NaOH) activator. Mater. Sci. Appl. 2017, 8, 537-552. [CrossRef]

48. Zaharaki, D.; Galetakis, M.; Komnitsas, K. Valorization of construction and demolition (C\&D) and industrial wastes through alkali activation. Constr. Build. Mater. 2016, 121, 686-693.

49. Bignozzi, M.C.; Manzi, S.; Lancellotti, I.; Kamseu, E.; Barbieri, L.; Leonelli, C. Mix-design and characterization of alkali activated materials based on meta-kaolin and ladle slag. Appl. Clay Sci. 2013, 73, 78-85. [CrossRef]

50. Li, Y.P.; Shen, L.; Mirmoghtadaei, R.; Ai, L. A design of experiment approach to study the effects of raw material on the performance of geopolymer concrete. Adv. Civ. Eng. Mater. 2017, 6, 526-549. [CrossRef]

51. Valentini, L.; Silvia Contessi, S.; Dalconi, M.C.; Zorzi, F.; Enrico Garbin, E. Alkali-activated calcined smectite clay blended with waste calcium.carbonate as a low-carbon binder. J. Clean. Prod. 2018, 184, 41-49. [CrossRef]

52. Konno, H.; Nanri, Y.; Kitamura, M. Crystallization of aragonite in the causticizing reaction. Powder Technol. 2002, 123, 33-39. [CrossRef]

53. Aboulayt, A.; Riahi, M.; Ouazzani Touhami, M.; Hannache, H.; Gomina, M.; Moussa, R. 2017. Properties of metakaolin based geopolymer incorporating calcium carbonate. Adv. Powder Technol. 2017, 28, 2393-2401. [CrossRef]

54. Cwirzen, A.; Provis, J.L.; Penttala, V.; Habermehl-Cwirzen, K. 2014. The effect of limestone on sodium hydroxide-activated metakaolin-based geopolymers. Construct. Build. Mater. 2014, 66, 53-62. [CrossRef]

55. Tekin, I.; Gencel, O.; Gholampour, A.; Oren, O.H.; Koksal, F.; Ozbakkaloglu, T. Recycling zeolitic tuff and marble waste in the production of ecofriendly geopolymer concretes. J. Clean. Prod. 2020, 268, 122298. [CrossRef]

56. Komnitsas, K. Co-valorization of marine sediments and construction \& demolition wastes through alkali activation. J. Environ. Chem. Eng. 2016, 4, 4661-4669.

57. Wang, Y.S.; Alrefaei, Y.; Dai, J.G. Silico-aluminophosphate and alkali-aluminosilicate geopolymers: A comparative review. Front. Mater. 2019, 6, 106. [CrossRef]

58. Jaya, N.A.; Al Bakri Abdullah, M.M.; Li, L.Y.; Sandu, A.V.; Hussin, K.; Ming, L.Y. Durability of metakaolin geopolymers with various sodium silicate/sodium hydroxide ratios against seawater exposure. AIP Conf. Proc. 2017, 1887, 020063.

59. Azarsa, P.; Gupta, R. Freeze-thaw performance characterization and leachability of potassium-based geopolymer concrete. J. Compos. Sci. 2020, 4, 45. [CrossRef]

60. Garcia-Lodeiro, I.; Carcelen-Taboada, V.; Fernández-Jiménez, A.; Palomo, A. Manufacture of hybrid cements with fly ash and bottom ash from a municipal solid waste incinerator. Constr. Build. Mater. 2016, 105, 218-226. [CrossRef] 